\title{
横行結腸導管造設術の経験
}

\author{
栃木県立がんセンター泌尿器科 \\ 萩 原 正通 中䕐 昌 明 \\ 国立杤木病院泌尿器科 \\ 浅野 友彦飯ヶ谷知彦塚本 拓司 朝倉 博孝
}

\section{EXPERIENCE WITH TRANSVERSE COLON CONDUIT URINARY DIVERSION}

\author{
Masamichi Hagiwara and Masaaki Nakazono \\ Department of Urology, Tochigi Cancer Center, Utsunomiya \\ Tomohiko Asano, Tomohiko Iigaya, Takuji Tsukamoto \\ and Hirotaka Asakura \\ Department of Urology, National Tochigi Hospital, Utsunomiya
}

Transverse colon conduit urinary diversion was performed in 8 patients with pelvic malignancy, which was uterine cancer in 1 patient, bladder tumor in 6 and prostate cancer in 1 . In 3 of these patients the transverse colon conduit was preferred to the ileal conduit because of a previous irradiation to the pelvic cavity which could have adversely affected the ileum and intrapelvic ureter. One patient, who developed bilateral hydronephrosis due to stenosis at the ureteroileal anastomosis sites following total cystectomy and ileal conduit for bladder tumor, underwent re-diversion using the transverse colon conduit. The ileal conduit was difficult to perform in this patient because of an extensive adhesion in the small intestine. The other 4 patients, who were expected to have a local recurrence after radical surgery, underwent the transverse colon conduit which was considered to be a favorable type of urinary diversion compared to the ileal conduit in the surgical manipulation and radiotherapy of the intrapelvic recurrent disease and was anticipated to delay urinary obstruction by the recurrent disease. The followup period of these patients ranged from 12 to 23 months (average 17 months). None of these patients except one who developed parastomal hernia at 6 months of follow up experienced postoperative complications. Hydronephrosis, which was seen on the preoperative excretory urogram in 3 patients, showed a marked improvement after the transverse colon conduit urinary diversion. The postoperative excretory urogram of 5 patients whose preoperative excretory urogram showed normal upper tract revealed mild hydronephrosis at 1 month of followup, which disappeared in most patients at 6 months of followup. None of these patients had a significant elevation of serum creatinine level after the transverse colon conduit, while one patient had an elevated preoperative serum creatinine level which became normal after the transverse colon conduit. No patients developed electrolyte disturbances.

要旨：骨盤内悪性腫瘍患者 8 例（子宮癌 1 例, 膀朕腫瘍 6 例, 前立腺癌 1 例) に横行結腸導管造設術を 施行した。 3 例は放射線治療後の患者で, 回腸および骨盤内尿管に対する放射線照射の影響を考慮し本 術式を施行した。1 例は膀胖腫瘍のため膀胱全摘と回腸導管造設術を受けたが尿管回腸吻合部狭窄のた め尿路再変更が必要となった症例で, 広範な腹膜癒着のため小腸を導管として使用できず, 本術式を施 行した。 その他の 4 例はいずれも腫瘍の骨盤内再発の可能性が高い症例で, 再発腫瘍の外科的または放 射線治療に際し尿路は骨盤外にあった方が好ましいであろうこと, 再発腫瘍による尿路閉塞が来たしに くいであろうことなどを推測し本術式を施行した。これらの症例の術後経過観察期間は12〜23力月（平 均17カ月）で, 術後早期合併症はなく, 晚期合併症として 1 例に parastomal hernia がみられた。排泄 性尿路造影では術前に水腎症を認めた 3 例では, 術後, 水腎症の著明な改善がみられた。術前に水腎症 を認めなかったその他の症例では, 術後 1 カ月の時点で全例に軽度水腎症を認めたが, 術後 6 力月には ほとんどの症例で水腎症の消失をみた。血清クレアチニン值が術後有意の上昇を示した症例はなく，術 
前上昇のみられた 1 例では術後正常化した。 また, 術後, 高クロール性アシドーシスなどの血清電解質 異常を来たした症例はなかった。

\section{緒言}

回腸導管造設術は現在最も一般的な尿路変更術式で あるが，骨盤内悪性腫瘍に対する放射線治療後に本術 式を行った場合，回腸吻合部や尿管回腸吻合部の縫合 不全, 尿管回腸吻合部狭窄などの術後合併症の発生率 が高いとされている $\mathrm{Golimbu}^{8)}$, Schmidt ら ${ }^{9)}$ により報告された横行結腸導 管造設術は，放射線の照射されていない横行結腸と高 位尿管を用いるため，放射線治療後の骨盤内悪性腫瘍 患者にもより安全に行光る尿路変更術として諸 家7)10) 13)により推奨されている。

われわれは，今回，放射線治療後の骨盤内悪性腫瘍 患者に横行結腸導管による尿路変更を行い，その安全 性を確認し党たので報告するとともに，最近では本術 式を放射線治療後の患者以外にも応用していることか ら，本術式の適応につき若干の考察を加觉る。

\section{対象}

横行結腸導管造設術を施行し, 術後 12 力月以上経過 を観察しえた 8 症例の背景を表 1 に示した。症例 1 は, 17年前に子宮癌のため広沉子宮全摘と放射線治療を受 けた既往があり，2 カ月前から膀胱膣瘦が出現し，尿 路変更が必要となった症例である，症例 2 は，18年前 に膀胱腫瘍のため経尿道的切除と放射線治療を受け, 2 年前から萎縮膀胱, 両側膀胱尿管逆流症および両側 水腎症のため尿道カテーテルが留置されてきた症例で ある。な报，本症例は 3 年前に急性腹症の診断で試験 開腹術を受けた既往がある。症例 3 は T4, N0，M0の 膀胼腫瘍患者で, $6,000 \mathrm{rad}$ のリニアック照射に引き続 き，膀胱全摘拈よび横行結腸導管造設術が行われた。 本症例は術後 13 力月で癌死した。症例 4,5 拈よび 7

表 1 横行結腸導管造設術施行症例.

\begin{tabular}{|c|c|c|c|c|}
\hline 症例 - 年令 - 性 & 術 & 前 & 診 & $\begin{array}{l}\text { 術後経過 } \\
\text { 観察期間 }\end{array}$ \\
\hline 1. H.M. -62-女 & \multicolumn{3}{|c|}{$\begin{array}{l}\text { 子宮癌(広汎子宮全摘および放射線治療後), } \\
\text { 膀胱窑廐 }\end{array}$} & 23力月 \\
\hline 2. T.T. - 45-男 & \multicolumn{3}{|c|}{$\begin{array}{l}\text { 膀胱腫痬 (経尿道的切除および放射線治療後), } \\
\text { 萎縮膀胱, 両側膀胱尿管逆流症, 両側水腎症 }\end{array}$} & 23カ月 \\
\hline 3. A.M. - 64-男 & \multicolumn{3}{|c|}{ 膀胱腫瘍（放射線治療後） } & 13カ月 \\
\hline 4. U.T. - 73-男 & \multicolumn{3}{|l|}{ 膀胱腫瘍 } & 20 カ月 \\
\hline 5. A.Y. - 82-女 & \multicolumn{3}{|l|}{ 膀胱腫瘍 } & 19カ月 \\
\hline 6. T.H. - 50-男 & \multicolumn{3}{|l|}{ 前立腺癌 } & 14カ月 \\
\hline 7. T.Y. - 51-男 & \multicolumn{3}{|l|}{ 膀胱腫瘍 } & 12力月 \\
\hline 8. H.T. -80 - 男 & \multicolumn{3}{|c|}{$\begin{array}{l}\text { 膀胱腫痬(膀胱全摘おょび回腸導管造設後), } \\
\text { 両/側尿管回腸吻合部狭窄 }\end{array}$} & 12力月 \\
\hline
\end{tabular}

は膀胱腫瘍に対し膀胱全摘，症例 6 は前立腺癌に対し 膀胱前立腺全摘を施行した症例であるが，術後骨盤内 再発の可能性が高いことから，横行結腸導管による尿 路変更を行った。症例 8 は，8 カ月前に膀胱腫瘍のた め膀胱全摘と回腸導管造設術を受けたが，尿管回腸吻 合部狭窄による両側水腎症を来たした症例である。

\section{手術手技}

注腸造影により使用する横行結腸に病変がないこと を確認後, 手術 3 日前より高蛋白流動食とし, 緩下剂 投与，浣腸およびカナマイシン投与により bowel preparationを行った。

麻酔は気管内捜管全身麻酔, 体位は仰臥位としたが, 前部尿道切除を行った症例（症例 4 抒よび 7 ）では截 石位とした。

皮膚切開は, 骨盤内臟器に手術操作を加える場合は 剣状突起から㑪左側を迂回し恥骨結合上縁に至る正中 切開, 横行結腸導管造設のみの場合は原則として上腹 部横切開にて開腹した。

導管用横行結腸 segment の選定にあたっては中結 腸動脈により支配された長さ20～25cm(結腸 segment は遊離後短縮するので長めにする）の segment を選 び, この segment を遊離しても残りの横行結腸への血 流が障害されないことを確認した。すなわち, 横行結 腸切離予定線上で marginal artery を圧迫し, 中結腸 動脈と左右結腸動脈との交通を遮断しても, 導管用 segment と残りの横行結腸への血流が保たれること を確認した。導管用 segment を選定したらここの範囲 の大網と胃結腸間膜を切離した。次に，中結腸動脈を 損傷しないように横行結腸間膜を横行結腸切離予定線 に向けて切開し，横行結腸を切離した。遊離された導 管用 segment の頭側で横行結腸の端端吻合を行い, 横 行結腸間膜を閉鎖した。

尿管之導管の吻合は，大動脈右側，右腎下極の高さ で, 粘膜下トンネル法(症例 1 から 3 までは McLoughlin らの open 法 ${ }^{14)}$, 症例 4 から 8 までは Leadbetter 法 ${ }^{15)}$ )を用いて行った(横行結腸間膜は長いため，遊離 した導管用 segment は可動性に富み，尿管との吻合 は，手技的には，大動脈の右側でも左側でも，また， 腎下極から大動脈分岐部屯でのどの高さでも可能であ る)。この際，尿管の走行，とくに左尿管の走行が可能 な限り直線的になるように後腹膜を十分に剝離すると 
図 1 症例 2 の尿管導管吻合終了時の術中写真.
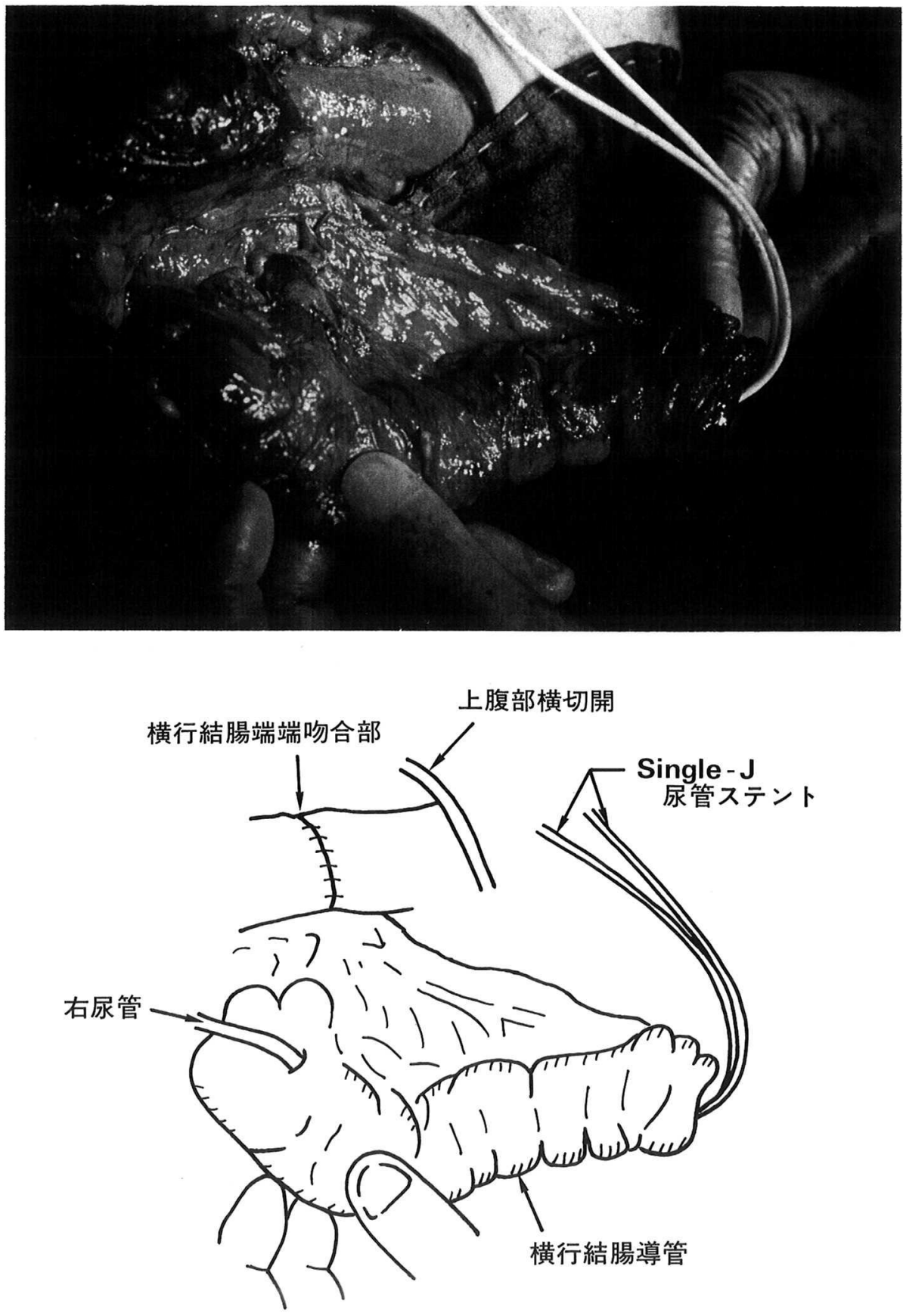

ともに， 7 または $8.5 \mathrm{Fr}$, single-J 尿管ステントを導管 ロから腎血内に留置した（図 1)。

尿管導管吻合部を後腹膜化し, 導管口は, protruding nipple stoma とし, 症例 1 から 7 までは㑪右側に, 症 例 8 は回腸導管を切除し同じ部位に作成した。
尿管導管吻合部付近の後腹膜腔と横行結腸吻合部近 くの腹腔内にドレーンを置き，導管内には22Fr，バ ルーンカテーテルを留置した。

術後 7 日目より経口摄取を開始し，14日目には single-J 尿管ステントと導管内留置カテーテルを抜去 
した。

\section{結 果}

横行結腸導管造設術の久を施行した症例 1,2 およ び 8 の手術時間は，それぞれ，6，7 扤よび 7 時間で あった。これらの症例では，既往の開腹手術によるも のと思われる広範な腹膜癒着があり, 横行結腸を剝離 するまでに長時間を要した。一方，原発巣に対する根 治手術を同時に施行した症例 3 から 7 香での手術時間 は 8 〜 時間で, 平均 9 時間であった。

以上のごとく，手術時間は全例でかなりの長時間に 及んだが, 術後 1 カ月以内の早期合併症（横行結腸縫 合不全, 疗瘦, 急性腎不全など)は全く認められなかっ た。

晚期合併症としては，症例 5 で術後 6 カ月に parastomal hernia が出現したが, 軽度かつ無症状であるた め，その末ま経過観察中である。その他の症例では， 現時点で, 晚期合併症と言えるもの（腎盂腎炎, 腎結 石，尿管導管吻合部狭窄，導管口狭窄，イレウスなど） を経験していない。
横行結腸導管造設に伴う上部尿路の変化を排泄性尿 路造影で観察すると(表 2), まず術前に水腎症を認め た症例 2,3 および 8 では, 術後, 中腎症が著明に改善 した(図 2).一方，術前に水腎症を認めなかったその 他の症例では, 術後 1 力月の時点で全例に軽度水腎症 が出現したが，この水腎症は術後 6 カ月の時点ではほ

表 2 横行結腸導管造設に伴う腎機能の変化. 水腎症 の有無は排泄性尿路造影 (IVP) の所見から判定し, その程度は岡分類に従い分類した。

\begin{tabular}{|c|c|c|c|c|}
\hline \multirow[b]{2}{*}{ 症 例 } & \multicolumn{2}{|r|}{ 前 } & \multicolumn{2}{|c|}{ 街後 12 力月 } \\
\hline & $\begin{array}{c}\text { 清クレアチニン值 } \\
\text { (mg/de) }\end{array}$ & 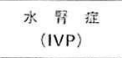 & $\begin{array}{c}\text { 血清クレアチニン值 } \\
(\mathrm{mg} / \mathrm{d} \ell)\end{array}$ & $\begin{array}{l}\text { 水 简 症 } \\
\text { (IVP) }\end{array}$ \\
\hline 1. H.M. & 0.8 & $(-)$ & 0.9 & 右:(一), 左: A \\
\hline 2. T.T. & 1.4 & 右: B, 左: D & 1.0 & 右: A, 左: C \\
\hline 3. A.M. & 1.2 & 右: B, 左: CD & 1.3 & 右: (-), 左: BC \\
\hline 4. U.T. & 1.4 & $\langle-\rangle$ & 1.0 & $(-)$ \\
\hline 5. A.Y. & 1.2 & $(-)$ & 0.8 & $(-)$ \\
\hline 6. T.H. & 0.9 & $(-)$ & 0.8 & $(-)$ \\
\hline 7. T.Y. & 1.0 & $(-)$ & 0.8 & $(-)$ \\
\hline 8. H.T. & 1.8 & 右: B, 左: C & 1.2 & 右:(一), 左:B \\
\hline
\end{tabular}

図 2 症例 2 の術前（左）招よび術後 6 カ月（右）の排泄性尿路造影像. 術前にみら れた左水腎症が術後著明に改善している.
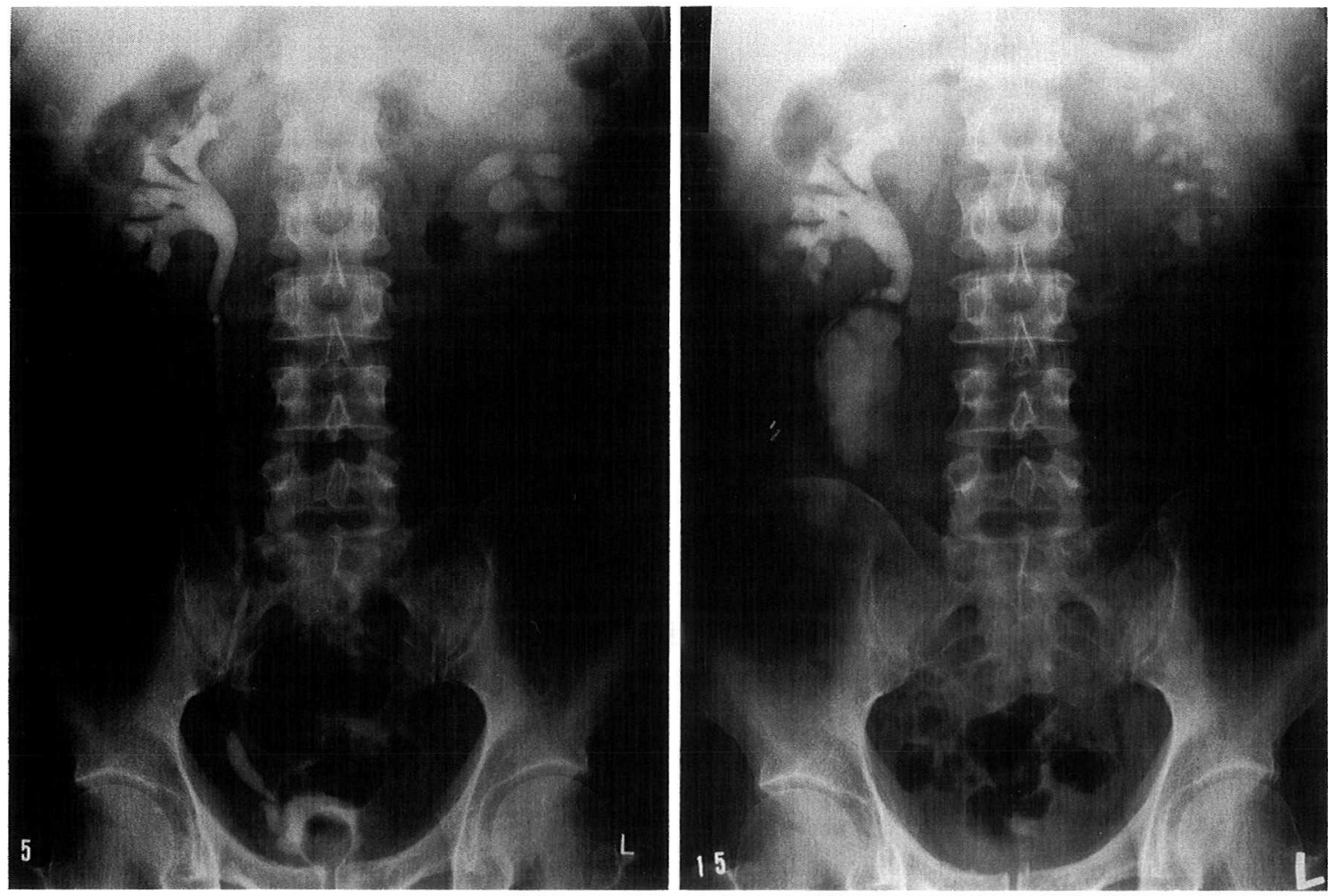
とんぞの症例で消失した。術前後の血清クレアチニン 值の推移をみると, 術後有意の上昇を示した症例はな く, 術前上昇のみられた症例 8 では術後正常化した。 また術後, 高クロール性アシドーシスなどの血清電解 質異常を来たした症例はなかった。

自験例では全例で粘膜下トンネル法による尿管導管 吻合が行われたが, 術後 6〜12カ月に拉ける導管造影 ( $30 \mathrm{~cm} \mathrm{H}_{2} \mathrm{O}$ の圧力で造影)では全例で尿管逆流を認め なかった。

\section{考 察}

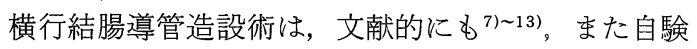
例をみても，比較的安全に施行できる尿路変更術式と 言えるが，導管用 segment の選定，大網や胃結腸間膜 に対する処置, 横行結腸端端吻合などの手技は回腸導 管造設術に比べより煩雑であり，手術時間もより長時 間とならざるをえない。また，尿管 $\mathrm{S}$ 状結腸吻合術施 行症例では結腸癌の発生率が 100 倍以上に高まると言 われて抢り ${ }^{16)}$ ，結腸を導管として用いた場合も導管粘 膜に抢ける癌発生率が高まる可能性がある。さらに, 結腸導管は, 当初, 回腸導管に優る尿路变更法として 期待されたが，長期経過観察の結果は必ずしもこの期 待に答えるものではなく，回腸導管を凌駕するには 至っていない16)。

以上のよらな横行結腸導管造設術に伴うと思われる 問題点を考慮に入れたらえでその適応について考えて みると，まず第 1 の適応は放射線治療後尿路変更が必 要となった骨盤内悪性腫瘍患者と思われる。既に述べ たように，放射線治療後の骨盤内悪性腫瘍患者に回腸 導管による尿路変更を行った場合，合併症，とくに早 期合併症の発生率が高いとされている(1) 7)。このよう な観察にもとづき，放射線治療後の骨盤内悪性腫瘍患 者にも安全に行兄る尿路変更術式として横行結腸導管 造設術が導入されたわけであるが8)99，その後の諸施設 からの追試報告7)10) 13) は本術式が当初の目的に適った ものであることを示している。われわれも，放射線治 療後の骨盤内悪性腫瘍患者 3 例に本術式を施行した が，術後合併症は全く認められず，本術式が放射線治 療後の骨盤内悪性腫瘍患者にも安全に行兄る尿路変更 法であるとの印象を受けた。

横行結腸導管造設術の第 2 の適応は，広範な腹膜癒 着のため回腸を導管として用いるのが困難な場合が考 えられる。自験例中症例 8 は, 回腸導管造設術後尿管 回腸吻合部狭窄をきたし，尿路再変更が必要となった 症例であるが，回腸導管造設術後 10 日間にわたりみら
れた尿瘻のためか小腸は相互に癒着し一塊となってお り，小腸を用いた導管の造設は困難と思われた。しか しながら，横行結腸における癒着は小腸ほど高度では なく，導管として使用可能な状態であった。熊本ら ${ }^{12}$, 石塚ら ${ }^{13)}$ も，広範な腹膜癒着を伴った開腹手術既往症 例でも横行結腸の癒着は軽度である場合が多いと述べ ている.

さらに。われわれは，術後局所再発の可能性が高い 骨盤内悪性腫瘍患者の尿路変更にも横行結腸導管を用 いている。その理由は, 骨盤内再発腫瘍による尿路閉 塞が来たしにくいであろうこと，また，機会は少ない ものの, 骨盤内再発腫瘍に対し外科的治療を行う場合 には, 尿路が術野から離れていた方が手術操作が容易 であろうこと, さらに, 補助療法または再発腫瘍に対 する治療として放射線照射を行ら場合にも，尿路が照 射野からはずれていた方が好ましいであろうことなど を推測したためであるが，これらの推測が正しいかど らかは今後の検討が必要である。

稿を終えるにあたり、御校閲をいただいた慶応義塾大学 医学部泌尿器科学教室 田崎 寛教授に深謝します。

\section{文献}

1) Galleher, E.P. Jr., Young, J.D. Jr., Mowad, J.J., Wizenberg, M.J. and Bloedorn, F.G.: A followup study of supervoltage irradiation followed by cystectomy for bladder cancer. J., Urol., 99, 59-64, 1968.

2) Johnson, D.E., Jackson, L. and Guinn, G.A.: Ileal conduit diversion for carcinoma of the bladder. South. Med. J., 63, 1115-1118, 1970.

3) Alfert, H.J. and Gillenwater, J.Y.: The consequences of ureteral irradiation with special reference to subsequent ureteral injury. J. Urol., 107, 369-371, 1972 .

4) Swan, R.W. and Rutledge, F.N.: Urinary conduit in pelvic cancer patients. A report of 16 years' experience. Am. J. Obstet. Gynecol., 119, 6-13, 1974.

5) Daughtry, J.D., Susan, L.P., Stewart, B.H. and Straffon, R.A. : Ileal conduit and cystectomy: A 10-year retrospective study of ileal conduits performed in conjunction with cystectomy and with a minimum 5-year follow-up. J. Urol., 118, 556-557, 1977.

6) Mänsson, W., Colleen, S. and Stigsson, L.: Four methods of ureterointestinal anastomosis in urinary conduit diversion. A comparative study of early and late complications and the influence of radiotherapy. Scand. J. Urol. Ne- 
phrol., 13, 191-199, 1979.

7) Orr, J.W. Jr., Shingleton, H.M., Hatch, K.D., Taylor, P.T., Austin, J.M. Jr., Partridge, E.E. and Soong, S.J.: Urinary diversion in patients undergoing pelvic exenteration. Am. J. Obstet. Gynecol., 142, 883-889, 1982.

8) Morales, P.A. and Golimbu, M.: Colonic urinary diversion: Ten years of experience. $\mathrm{J}$. Urol., 113, 302-307, 1975.

9) Schmidt, J.D., Hawtrey, C.E. and Buchsbaum, H.J.: Transverse colon conduit: A preferred method of urinary diversion for radiationtreated pelvic malignancies., J. Urol., 113, 308 $-313,1975$.

10) Loening, S.A., Navarre, R.J., Narayan, A.S. and Culp, D.A.: Transverse colon conduit urinary diversion. J. Urol., 127, 37-39, 1982.

11) Beckley, S., Wajsman, Z., Pontes, J.E. and Murphy, G.: Transverse colon conudit: A method of urinary diversion after pelvic irradiation. J. Urol., 128, 464-468, 1982.

12）熊本悦明, 塚本泰司, 広瀬崇興: 横行結腸導管造設 術. 臨泌, 40, 445-449, 1986.

13）石塚 修, 福井準之助, 小川秋実：腎瘻, 尿管瘦力 ら腸管利用皮膚瘻への再変更. 臨泌, 41, 129-131, 1987.

14) McLoughlin, M.G., Marshall, F.F. and Jeffs, R. D. : Open ureterocolonic anastomoses. J. Urol., 118, 729-730, 1977.

15) Leadbetter, W.F.: Consideration of problems incident to the performance of ureteroenterostomy : Report of a technique. J. Urol., 65, 818 $-830,1951$.

16) Walsh, A.: Urinary diversion in malignant disease. in Urinary Diversion, Ashken, M.H., p. 75-100, Springer-Verlag, Berlin/Heidelberg/ New York, 1982.

（1987年 4 月 4 日受理） 